Available online on 15.01.2020 at http://jddtonline.info
Open Access to Pharmaceutical and Medical Research
unrestricted non-commercial use, provided the original work is properly cited

Open 2 Access

Research Article

\title{
Formulation and Evaluation of Herbal Topical Gel Containing Leaves Extract of Andrographis paniculata
}

\author{
Samuel Aney J. *, Mulla Nida \\ Department of Pharmaceutics, Allana College of Pharmacy, Savitribai Phule Pune University, Pune-411001, Maharashtra, India
}

\begin{abstract}
Objective: The present study has been undertaken with the aim to formulate and evaluate the gel contaning leaf extract of Andrographis Paniculata.
\end{abstract}

Methodology and results: The formulation was designed by using alcoholic extract of leaves of Andrographis paniculata.The gel was prepared by using carbapol 934, triethanolamine, propylene glycol, methyl paraben, propyl paraben and required amount of distilled water. The prepared gel was evaluated for physical appearance, $\mathrm{pH}$, spread ability, viscosity, extrudability, albumin denaturation assay and stability.

Conclusion: Carbopol gels with dried leaves extract of Andrographis paniculata could be prepared successfully.

Key words: Topical gel,Kalmegh, Spreadability, Albumin denaturation.

Article Info: Received 23 Nov 2019; Review Completed 17 Dec 2019; Accepted 29 Dec 2019; Available online 15 Jan 2020

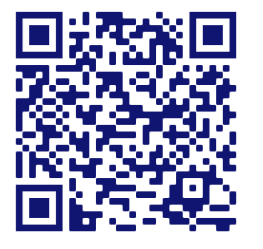

Cite this article as:

Samuel AJ, Mulla N, Formulation and Evaluation of Herbal Topical Gel Containing Leaves Extract of Andrographis paniculata, Journal of Drug Delivery and Therapeutics. 2020; 10(1):48-51 http://dx.doi.org/10.22270/jddt.v10i1.3837

*Address for Correspondence:

411001,Maharashtra, India

\section{INTRODUCTION}

Andrographis paniculata (AP) commonly known as Kalmegh in Hindi, Kalamegha in Sanskrit and Kalmeghin Bengali is an erect herb belonging to family Acanthaceae. It is found in India especially in Tamil Nadu, Karnataka, Maharashtra, Orissa, Uttar Pradesh and Uttarakhand. Andrographis paniculata (Burm.f.) Nees is one of the important herbs among 17,000 higher plant species occurring in India, out of which more than 1000 species are used over several centuries in the traditional systems of medicine viz. Ayurveda, Siddha and Unani. Morphological characteristics could have different chemical constituents and physiological variation but also plants with similar morphological features and growing on the same site may have different contents of chemical constituents and physiological variation. Andrographis paniculata or Kalmegh is one of the most widely used plants in ayurvedic formulation. Crude and alcoholic extracts of AP have been reported to have wide variety of pharmacological activities. Topical application of gels at pathologic sites after great advantage in faster release of drug delivery to site of action. The present investigation involves the preparation of gel formulation of alcoholic extract of leaves of Andrographis paniculata followed by the evaluation for physical appearance, $\mathrm{pH}$, viscosity, spread ability, extrudability, albumin denaturation assay and stability ${ }^{1,2}$.

\section{MATERIALS AND METHODS}

Carbopol 934 (Research-lab fine chem. industries Mumbai), Triethanolamine (Research-lab fine chem. industries Mumbai), Propylene glycol(Research-lab fine chem. industries Mumbai), Methyl paraben (Research-lab fine chem. industries Mumbai), Propyl Paraben (Lab and General exports Pvt. Ltd., Bangalore)

\section{Preparation of ethanolic extracts:}

The dried leaves of Andrographis paniculata were obtained from the local market. 20gm of dried leaves powder of Andrographis paniculata were macerated with $200 \mathrm{~mL}$ of alcohol in a round bottom flask, heated until it boiling then kept 15 min for cooling, stand for 2-3 hours separately. Thereafter, it was filtered rapidly taking precaution to minimize the loss of alcohol. Percentage of alcohol soluble extractive was calculated with reference to the air dried sample ${ }^{1}$. 


\section{Method of preparation of gel containing extract:}

The Carbopol934was dispersed in $10 \mathrm{ml}$ of distilled water, kept the beaker aside for half an hour for it to swell and then stirring was done to form gel. Required quantity of methyl paraben, propyl paraben and triethanolamine was dissolved in propylene glycol. Triethanolamine was slowly added to the dispersion with continuous stirring. Further, required quantity of Andrographis paniculata leaves extract was mixed to the above mixture and volume was made up to $10 \mathrm{ml}$ by adding remaining distilled water. The composition of herbal gel prepared from ethanolic extract of Andrographis paniculata is tabulated in the following table 2,3,4.

Table 1: Formulation table

\begin{tabular}{lllll}
\hline \multirow{2}{*}{ Sr No } & Ingredient & \multicolumn{2}{l}{ Formulation } & \\
\cline { 3 - 5 } & Extract $(\mathrm{g})$ & $\mathrm{G} 1$ & $\mathrm{G} 2$ & $\mathrm{G} 3$ \\
\hline 1 & Carbapol 934(g) & 0.1 & 0.1 & 0.1 \\
\hline 2 & Triethanolmine $(\mathrm{ml})$ & 0.05 & 0.5 & 0.2 \\
\hline 3 & Propyleneglycol(ml) & 0.5 & 5 & 0.5 \\
\hline 4 & Methyl paraben(g) & 5 & 0.02 & 0.02 \\
\hline 5 & Propyl paraben(g) & 0.02 & 0.05 & 0.05 \\
\hline 6 & Water QS to (g') & 0.05 & 10 & 10 \\
\hline 7 & & 10 & & 5 \\
\hline
\end{tabular}

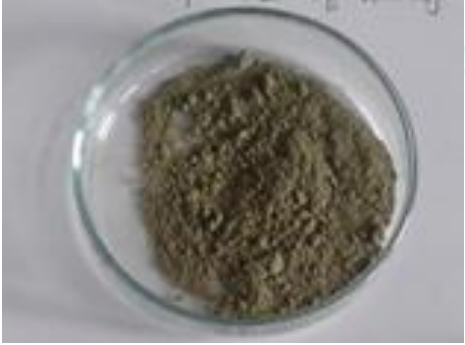

Fig. 1: Dried powder

\section{Evaluation of dried powder of Andrographis paniculata}

\section{Determination of Ash value}

Total ash (TA) value: This value was determined using a minimum of 2.0-3.0 $\mathrm{g}$ of material in a furnace heated gradually to the ignition temperature of $650-700^{\circ} \mathrm{C}$. Accurately 2 to $3 \mathrm{~g}$ of air-dried samples of Andrographis paniculata were weighed in a tared silica dish and incinerate at a temperature not exceeding $700^{\circ} \mathrm{C}$ until ash free from carbon is obtained. Then it was cooled and weighed. The process was repeated until at least two consecutive constant weights were obtained. The results are expressed as range or mean value standard deviation. The percentage of ash was calculated with reference to the air - dried drug.

Determination of acid insoluble ash (AIA): Above obtained ash was boiled with $25 \mathrm{~mL}$ of $2 \mathrm{M}$ hydrochloric acid for $5 \mathrm{~min}$, the insoluble matter was collected in a Gooch crucible or on an ash less filter paper, washed with hot water, ignited and cooled in desiccators. Then it was weighed. The percentage of acid insoluble ash was calculated with reference to the air-dried drug.

Determination of water soluble ash (WSA): Ash was boiled for $5 \mathrm{~min}$. with $25 \mathrm{~mL}$ of water; the insoluble matter was collected in a Gooch crucible or on an ash less filter paper, washed with hot water, and ignited for $15 \mathrm{~min}$ at a temperature not exceeding $450^{\circ} \mathrm{C}$. The weight of insoluble matter was subtracted from the weight of the ash, the difference in weight represent the water-soluble ash. The percentage of water-soluble ash was calculated with reference to the air-dried drug.

Loss on drying (LOD): Loss on drying of the air-dried samples of Andrographis paniculata was analyzed. This was carried out using a minimum of $0.5-1.0 \mathrm{~g}$ of material. Accurately weighed quantity of sample was taken in a tared glass bottle and initial weight was taken. The sample was heated in an oven maintained at $105-110^{\circ} \mathrm{C}$, for $3 \mathrm{~h}$, after which the sample was allowed to cool to room temperature in desiccators, and subsequently weighed.

\section{Phytochemical Investigation ${ }^{3}$ :}

Test for Alkaloids Crude extract was mixed with $2 \mathrm{ml}$ of Wagner's reagent. Reddish brown colored precipitate indicated the presence of alkaloids.

Test for Cardiac Glycoside Keller-Kelliani test was performed to detect cardiac glycoside. Five ml of extract was treated with $2 \mathrm{ml}$ of glacial acetic acid containing one drop of ferric chloride solution. This was underlayed with $1 \mathrm{ml}$ of concentrated $\mathrm{H} 2 \mathrm{SO} 4$. brown ring of the interface indicated a deoxysugar characteristic of cardenolides. A violet ring may appear below the brown ring, while in the acetic acid layer, a greenish ring may form just gradually throughout thin layer.

Test for Flavanoids Alkaline reagent test was performed to test the presence of flavonoids. Crude extract was mixed with $2 \mathrm{ml}$ of $2 \%$ solution of $\mathrm{NaOH}$. An intense yellow colour was formed which turned colourless on addition of few drops of diluted acid which indicated the presence of flavonoids. 
Evaluation of herbal gel 3,4,5:

Appearance and Homogeneity: Physical appearance and homogeneity of the prepared gels were evaluated by visual inspection ${ }^{2}$.

pH: pH measurement of the gel was carried out using a digital $\mathrm{pH}$ meter by dipping the glass electrode completely into the gel system to cover the electrode. The measurement was carried out in triplicate and the average of the three readings was recorded ${ }^{2}$.

Viscosity: Viscosity of gel was determined using Brookfield viscometer (Model CAP2000+)at $25^{\circ} \mathrm{C}$ with a spindle speed of the viscometer rotated at $12 \mathrm{rpm}$.

Spreadablity: Two sets of glass slides of standard dimensions were taken. The herbal gel formulation was placed over one of the slides. The other slide was placed on the top of the gel, such that the gel was sandwiched between the two slides in an area occupied by a distance of $7.5 \mathrm{~cm}$ along the slides. $100 \mathrm{gm}$ weight was placed on the upper slides so that the gel between the two slides was pressed uniformly to form a thin layer. The weight was removed and the excess of gel adhering to the slides was scrapped off. The two slides in position were fixed to a stand without slightest disturbance and in such a way that only upper slides to slip off freely by the force of weight tied on it. A $20 \mathrm{~g}$ weight was tied to the upper slide carefully. The time taken for the upper slide to travel the distance of $7.5 \mathrm{~cm}$ and separated away from the lower slide under the influence of the weight was noted. The experiment was repeated for three times and the mean time was taken for calculation ${ }^{2}$.Spreadability was calculated by using the following formula:

$\mathrm{S}=\mathrm{m} \times \mathrm{l} / \mathrm{t}$

where, $\mathrm{S}=$ spreadability, $\mathrm{m}$-weight tied to upper slides $(20$ $\mathrm{g})$, l- length of the glass slide $(7.5 \mathrm{~cm})$, t- time taken in sec.

Extrudability: The gel formulations were filled in standard capped collapsible aluminum tubes and sealed by crimping to the end. The weights of tubes were recorded. The tubes were placed between two glass slides and were clamped. $500 \mathrm{gm}$ was placed over the slides and then the cap was removed. The amount of the extruded gel was collected and weighed $^{3}$. The percent of the extruded gel was $(>90 \%$ extrudability: excellent, $>80 \%$ extrudability: good,

$>70 \%$ extrudability: fair).

In-Vitro Anti-inflammatory activity (Inhibition of Albumin): The extract was screened for anti-inflammatory activity by using inhibition of albumin denaturation technique. Test solutions containing different concentration of extract was mixed with $0.2 \mathrm{ml}$ of egg albumin and $2.8 \mathrm{ml}$ of phosphate buffered saline (PBSpH6.4). The samples were incubated at $37^{\circ} \mathrm{C}$ for $15 \mathrm{~min}$ and heated at $70^{\circ} \mathrm{C}$ for $5 \mathrm{~min}$. After cooling the absorbance was measured at $660 \mathrm{~nm}$ in UV-
Vis spectrophotometer. The percentage inhibition of protein denaturation was calculated using the formula $6,7,8 \%$ inhibition $=(\mathrm{Vt} / \mathrm{Vc}-1) * 100$

Were $\mathrm{Vt}=\mathrm{Absorbance}$ of test sample and $\mathrm{Vc}=$ Absorbance of control

Stability study: Stability studies were performed as per ICH (International Conference on Harmonization) guidelines. The formulated gel was filled in the collapsible tubes and stored at different temperatures and humidity conditions, viz., $25^{\circ} \mathrm{C} \pm 2{ }^{\circ} \mathrm{C}$ and $60 \% \pm 5 \% \mathrm{RH}, 30^{\circ} \mathrm{C} \pm 2{ }^{\circ} \mathrm{C}$ and $65 \% \pm$ $5 \% \mathrm{RH}, 40^{\circ} \mathrm{C} \pm 2{ }^{\circ} \mathrm{C}$ and $75 \% \pm 5 \% \mathrm{RH}$ for a period of three months and studied for changes in appearance, $\mathrm{pH}$ and spreadability 2

\section{RESULTS AND DISCUSSION}

The herbal gels were prepared and evaluated for various parameters. The gel was greenish in colour with translucent appearance. The $\mathrm{pH}$ of the gel formulations were in the range of 7.1 to 7.2. Viscosity and spreadability was measured to ensure uniform application of gel. Extrudability was excellent but was found that concentration of carbopol affects viscosity of the gel. Anti-inflammatory activity of the extracts was carried out by screening it for albumin inhibition method.

Table 2: Properties of Extract

\begin{tabular}{ll}
\hline Parameter & Observation \\
\hline Colour & Green \\
\hline Odour & Odourless \\
\hline Appearance & Translucent \\
\hline Extractive value & $0.36 \mathrm{~g}$ \\
\hline
\end{tabular}

Table3: Determination of Ash values

\begin{tabular}{lll}
\hline Sr No & Parameters & Ash values (\%w/w) \\
\hline 1 & Total Ash & $9 \%$ \\
\hline 2 & Acid insoluble Ash & $2.10 \%$ \\
\hline 3 & Water soluble ash & $1.50 \%$ \\
\hline 4 & LOD & $10.50 \%$ \\
\hline
\end{tabular}

Table 4: Results of phytochemical evaluation

\begin{tabular}{lll}
\hline Test & Observation & Result \\
\hline Alkaloid & $\begin{array}{l}\text { Reddish brown } \\
\text { colored precipitate }\end{array}$ & Alkaloid present \\
\hline Glycoside & Brown ring & Cardiac glycoside present \\
\hline Flavonoid & Yellow color & Flavonoids Present \\
\hline
\end{tabular}

Table5: Evaluation of gel

\begin{tabular}{|c|c|c|c|c|c|}
\hline \multirow{2}{*}{ Sr no. } & \multirow{2}{*}{ Carbapol 934} & \multirow{2}{*}{ Physical appearance of gel } & \multirow{2}{*}{$\mathrm{pH}$} & Viscosity & Spreadabality \\
\hline & & & & (poise) & ( $\mathrm{g} \mathrm{cm} / \mathrm{sec})$ \\
\hline 1 & $0.05 \mathrm{~g}$ & $\begin{array}{l}\text { Green, smooth and } \\
\text { Translucent }\end{array}$ & 7.1 & 0.372 & 26.78 \\
\hline 2 & $0.1 \mathrm{~g}$ & $\begin{array}{l}\text { Greenish, smooth and } \\
\text { translucent }\end{array}$ & 7.2 & 0.365 & 37.5 \\
\hline 3 & $0.2 \mathrm{~g}$ & Greenish Sticky & 7.2 & 0.389 & 44.11 \\
\hline
\end{tabular}


Table6: Extrudability in the initial month

\begin{tabular}{lc}
\hline Extrudability & Mean of three tubes \\
\hline Net wt of formulation in tube $(\mathrm{g})$ & 12.34 \\
\hline Wt of gel extruded $(\mathrm{g})$ & 11.32 \\
\hline Extrudability (percentage) & 91.73 \\
\hline
\end{tabular}

Table7: Anti-inflammatory activity

\begin{tabular}{ccc}
\hline Extract code & Absorbance values & Inhibition of denaturation (\%) \\
\hline Control & 0.0939 & - \\
\hline E1 & 0.1139 & 21.3 \\
\hline E2 & 0.1772 & 88.71 \\
\hline E3 & 0.2443 & 160.17 \\
\hline E4 & 0.2889 & 207.66 \\
\hline E5 & 0.3074 & 277.36 \\
\hline
\end{tabular}

Table8: Stability study of G2formulation

\begin{tabular}{|c|c|c|c|c|}
\hline \multicolumn{5}{|c|}{ At $25^{\circ} \mathrm{C} \pm 2^{\circ}$ Cand $60 \% \pm 5 \%$ RH } \\
\hline \multirow{2}{*}{ Parameters } & \multicolumn{4}{|c|}{ Months } \\
\hline & $\mathbf{0}$ & 1 & 2 & 3 \\
\hline Appearance & Homogeneous & Homogeneous & Homogeneous & Homogeneous \\
\hline $\mathrm{pH}$ & 7.2 & 7.2 & 7.2 & 7.2 \\
\hline Spreadability (g cm/sec) & 37.5 & 37.5 & 37.5 & 37.5 \\
\hline \multicolumn{5}{|c|}{ At $30^{\circ} \mathrm{C} \pm 2^{\circ} \mathrm{C}$ and $65 \% \pm 5 \% \mathrm{RH}$} \\
\hline Appearance & Homogeneous & Homogeneous & Homogeneous & Homogeneous \\
\hline $\mathrm{pH}$ & 7.2 & 7.2 & 7.2 & 7.2 \\
\hline Spreadability (g cm/sec) & 37.5 & 37.5 & 37.5 & 38.5 \\
\hline \multicolumn{5}{|c|}{ At $40^{\circ} \mathrm{C} \pm 2^{\circ} \mathrm{C}$ and $75 \% \pm 5 \% \mathrm{RH}$} \\
\hline Appearance & Homogeneous & Homogeneous & Homogeneous & Homogeneous \\
\hline $\mathrm{pH}$ & 7.2 & 7.2 & 7.2 & 7.2 \\
\hline Spreadability (g cm/sec) & 37.5 & 37.5 & 38.5 & 38.5 \\
\hline
\end{tabular}

\section{CONCLUSION}

The various properties of the prepared gel formulations were evaluated and it is inferred from results that the gel formulations are good in physical appearance, homogeneity and spreadability.

Further studies to be performed to confirm its anti-microbial and anti-inflammatory effects.

\section{ACKNOWLEGMENT}

The authors express their sincere thanks to the Management andPrincipal of Allana College of Pharmacy, Pune for providing research facilitiesand the encouragement.

\section{REFERENCES}

1. Sharma M, Sharma RG, Sharma A. Study of physicochemical properties of drug \& physiological variation in leaves of Andrographis paniculata (BURM.F.) Nees. ActaChim. Pharm. Indica 2013; 3(1):52-64.

2. Shobha M, Roopashree TS. Antiacne \& wound healing activity of polyherbal topical gel comprising Andrographispaniculata (Burm.f.) Wall.ex nees, GlycyrrhizaglabraL, Carica papaya L. and Cucurbitapepo L. Annals of Phytomedicine 2017; 6(1):114-120.

3. Khandelwal KR, Sethi V Practical pharmacognosy: ISBN NO 978-81-85790-30-5 Twenty Fourth Edition Aug 2014.

4. Rajasekaran A, Govindarjan A, Ramasamy A. Formulation and evaluation of topical gel for the treatment of arthritis in animal model. BJPS 2016; 52.

5. Misal G, Dixit G and Gulkari V. Formulation \&evaluation of herbal gel: Indian Journal of Natural Products and Resources 2012; 3(4)501-505.

6. Reddy J.S., Lobo R., Prasanthi D., Shreedhara C.S., Pai A. Investigation of Anti- Inflammatory Potentials of Terminalia tomentosa Wight \& Arn. Bark-An In-Vitro approach Journal of Global Pharma Technology 2017; 9(8):1-5.

7. Santhosh Kumar Gupta, Amit Gupta, Dhirendra Prakash, Vedpal In-vitroAntiArthratic Activity of Ethanolic extract of CalliccarpaMacrophylla Flower Int. Res. J. Pharm. 2013; 4(3):160-162.

8. Somnath De, Dulal Chandra Das, Tansuri Manda, In vitro Antiinflammatory and Anti-Diabetic activity of methanolic extract of CardantheraDifformisdruce Int. Res. J. Pharm. 2016; $7(12): 56-60$ 